\title{
A Study on Systematic Direction of the Building Regulatory Information of Korea
}

\author{
Hwang Eun-Kyoung ${ }^{1, \text { a }}$, You Young-Chan ${ }^{2, b}$ \\ ${ }^{12}$ Senior Research Fellow, Korea Institute of Civil Engineering and Building Technology, \\ South Korea \\ a ekhwang@kict.re.kr bycyou@kict.re.kr
}

Keywords: Korean Building Code, Information of Regulation, Classification

Abstract. The current regulations related to building are scattered in more than 370 individual laws. Since the amendment of existing regulations and the legislation of new regulation have been going on, it is difficult to grasp the relevant regulations. Accordingly, in order to avoid duplication and to make systemizing individual laws easier, the regulations scattered in individual laws need to be classified. The aim of this study is to find ways to organize the information that is dispersed in numerous laws.

\section{Introduction}

Construction-related standards and procedures are increasingly becoming segmented, diversified, complicated, and specialized due to improved awareness of the people with regard to buildings and social demand responding for climate changes as well as enlargement, complexation, and high rising of buildings. However, since legislation is established centered on ministries of governments and departments, there are limits to understand the building regulations scattered in individual acts. In 2000, the Building Act declared construction-related integrated standards for reference in case of construction permission and change of building usage for conducting systematic construction administration through an organic relationship with construction-related legislations regulated in individual acts. In 2014, the public notice standard for integration of building-related regulations standard was newly established for reasonable operation and regulation guidance that are scattered in individual acts.

However, it is difficult to grasp to which legislation building-related regulations are scattered in, and there are no specific plans on how to classify regulations scattered in individual acts and how to provide regulated information to users.

Therefore, the study aims to understand the status of buildingrelated regulations scattered in individual acts and seeks to the measures to develop building regulat ion information systems to be utilized in construction activities by various users including building regulation makers of central administration organization, construction licensors, constructionrelated experts, and the public.

\subsection{Method and Procedure}

The study is implemented in order of understanding the status of building-related regulations scattered in individual acts and examining various building regulations systematic plans.

First, building-related regulations scattered in individual acts were derived through analysis of individual acts specified in the Building Act, the existing research literature, and the review of regulations submitted at the time of construction permission. Especially, sine existing literature and review of regulations cannot immediately reflect the related act which is frequently enacted and revised, revision of the literature and review was also conducted based on the current act.

Furthermore, the study aimed to seek the measures that building-related regulation system meets user demand based on the Building Act which is the foundation of construction.

\section{The status of individual acts related to building regulations}

Since the building-related acts are enacted, revised, or established by individual departments of central ministries, it is difficult to grasp the status of acts in operation. As a result of putting together 
the existing acts and literature based on the current acts of the National Legal Information Center, 369 acts are in operation. The Ministry of Land, Infrastructure, and Transport was found to operate the most of building acts (73 acts), followed by the Ministry of Trade, Industry and Energy (30 acts), the Ministry of Environment (28 acts), and the Ministry of Public Safety and Security (23 acts).

Table 1 A case study of individual regulations related to building

\begin{tabular}{c|c|c|c|c|c}
\hline Order & $\begin{array}{c}\text { Central Administration } \\
\text { Organization }\end{array}$ & $\begin{array}{c}\text { The } \\
\text { Number of } \\
\text { Acts }\end{array}$ & Order & $\begin{array}{c}\text { Central Administration } \\
\text { Organization }\end{array}$ & $\begin{array}{c}\text { The } \\
\text { Number of } \\
\text { Acts }\end{array}$ \\
\hline 1 & $\begin{array}{c}\text { Ministry of Land, } \\
\text { Infrastructure, and } \\
\text { Transport }\end{array}$ & 73 & 5 & $\begin{array}{c}\text { Ministry of Culture, } \\
\text { Sports and Tourism }\end{array}$ & 22 \\
\hline 2 & $\begin{array}{c}\text { Ministry of Trade, } \\
\text { Industry and Energy }\end{array}$ & 30 & 6 & $\begin{array}{c}\text { Ministry of Government } \\
\text { Administration and } \\
\text { Home Affairs }\end{array}$ & 19 \\
\hline 4 & $\begin{array}{c}\text { Ministry of } \\
\text { Environment }\end{array}$ & $\begin{array}{c}\text { Ministry of Public } \\
\text { Safety and Security }\end{array}$ & 23 & Total & $\begin{array}{c}\text { Others } \\
\text { Department }\end{array}$ \\
\hline
\end{tabular}

\section{Systematic Direction of the Building Regulatory Information}

\subsection{Review on the necessity of systematic building regulatory information}

In general, users who use building regulations are broadly divided into building regulation makers, construction licensors, construction-related experts, and the public.

One of the important purposes for setting systematic building regulations with consideration for users is to enable building regulation makers to mutually operate all acts scattered in individual acts. By doing so, it makes them to enact, revise or newly establish related acts without being duplicated or conflict between individual acts. Construction licensors can lighten burden or responsibility of civil affairs associated with omission of relevant acts during licensing. Construction experts including architectural designers can systematically grasp acts to be applied for construction, thereby preventing temporal and economic loss often caused by reprocessing and responsibility related to omitted legislations. While the public can have various interests, they can also grasp sizes and use of a building which one will build with his or her own assets and also understand overall construction activities.

\subsection{Systematic direction of the building regulatory information}

What needs to be considered the most in setting systematic building regulatory information is that all building regulations scattered in individual acts must be included without any omission and ensure easy access to building regulation information.

However, there is a limit in organizing construction regulations scattered in 369 acts into one information system to provide regulation information services for various demand of users. Hence, instead of unifying construction regulation information systems, it is necessary to provide various information systems for various demands of users. That is, it is required to develop a basic information system that can include all construction regulation information and measures to reconstruct building regulations that meet user demand.

With this in mind, the study has classified the basic information system into building administrative regulations and building application regulations that can include all types of building regulation information through various reviews on building regulation information system and collection of experts' opinions focusing on users because while Korea ensures exercise of the right of property, such exercise should be within the appropriate range of the public welfare. For this, the activity of the public is limited through building administrative regulations.

Building administration and lifelong stage-centered building regulation information systems are 
critical information for construction-related experts who implement construction for the public and the public officers in charge of licensing; therefore, the information system separates the regulations from general regulations. Also, since regulations applied for buildings are often associated with building administrative regulations and applied repeatedly, the regulations separated from the administration standard.

Furthermore, regulations applied to buildings are systematized based on construction stages, such as design, construction, supervision, maintenance, safety inspection and examination. This is to systemize regulations by construction stages for the guidance of legislation regulations and reasonable operation relevant to design, construction, supervision, maintenance associated with "Integration Notice of Building-related Regulations" specified in Article 68-2 of the Building Act. These regulations by construction stages are classified into construction, electricity, information and communication, and firefighting sectors.

In general, review of building qualities is conducted from the design stage. Some individual acts separately regulate various influence assessments and certification systems, thus, this study systemized them by separating from general regulations. The location also needs to be reviewed prior to design stage, so it also separated from design stage.

However, in the perspective of regulation information service users, there are difficulties in finding regulation information if too many regulation information access stages are provided. Of the construction stage, the study regulated some of the building design standard in the first stage and ensured access to regulation information within three stages.

Table 2 Building regulation information systems based on building administration and lifelong stages (plan)

\begin{tabular}{|c|c|c|}
\hline Stage 1 & Stage 2 (Example) & Stage 3 (Example) \\
\hline $\begin{array}{l}\text { Building administration } \\
\text { Procedure regulation }\end{array}$ & $\begin{array}{l}\text { Prior determination, deliberation, permission, } \\
\text { filing, approval, confirmation }\end{array}$ & $\begin{array}{l}\text {-Construction } \\
\text { deliberation and } \\
\text { permission }\end{array}$ \\
\hline Location regulation & $\begin{array}{l}\text { Usage, areas, districts, development activity } \\
\text { permissions/restrictions }\end{array}$ & \\
\hline $\begin{array}{l}\text { Assessment regulations of } \\
\text { various influences }\end{array}$ & $\begin{array}{c}\text { Traffic, disaster, environmental influence } \\
\text { assessment }\end{array}$ & $\begin{array}{l}\text { - Targets, procedures, } \\
\text { standards }\end{array}$ \\
\hline $\begin{array}{l}\text { Various certification } \\
\text { regulations }\end{array}$ & $\begin{array}{l}\text { Intelligent buildings, green buildings, long-life } \\
\text { housing }\end{array}$ & $\begin{array}{l}\text { - Targets, procedures, } \\
\text { standards }\end{array}$ \\
\hline Building design regulations & $\begin{array}{c}\text { Usage, planning, structures, energy, environment, } \\
\text { and facilities }\end{array}$ & $\begin{array}{l}\text { - Building use } \\
\text { classifications }\end{array}$ \\
\hline $\begin{array}{l}\text { Electricity design } \\
\text { regulations }\end{array}$ & Indoor and outdoor facilities & \\
\hline $\begin{array}{c}\text { Information and } \\
\text { communication design } \\
\text { regulations }\end{array}$ & $\begin{array}{l}\text { Local communication facilities, broadcasting } \\
\text { community reception systems, broadcasting } \\
\text { facilities }\end{array}$ & -Conduit facilities \\
\hline $\begin{array}{l}\text { Firefighting design } \\
\text { regulations }\end{array}$ & $\begin{array}{l}\text { Firefighting facilities, firefighting-target } \\
\text { buildings }\end{array}$ & \\
\hline Construction regulations & $\begin{array}{l}\text { Construction, electricity, information and } \\
\text { communication, firefighting }\end{array}$ & $\begin{array}{l}\text {-Business, } \\
\text { compensation }\end{array}$ \\
\hline Supervision regulations & $\begin{array}{l}\text { Construction, electricity, information and } \\
\text { communication, firefighting }\end{array}$ & $\begin{array}{l}\text {-Business, } \\
\text { compensation }\end{array}$ \\
\hline Maintenance regulations & $\begin{array}{l}\text { Construction, electricity, information and } \\
\text { communication, firefighting }\end{array}$ & $\begin{array}{l}\text {-Business, } \\
\text { compensation }\end{array}$ \\
\hline $\begin{array}{c}\text { Safety inspection and } \\
\text { diagnostic regulations of } \\
\text { buildings }\end{array}$ & $\begin{array}{l}\text { Safety inspections of the existing buildings, } \\
\text { facilities, and housing rebuilding }\end{array}$ & $\begin{array}{l}\text {-Inspection target, } \\
\text { procedures, methods }\end{array}$ \\
\hline
\end{tabular}




\section{Conclusion}

As a measure for systemization of building-related regulation information scattered in individual acts, the study suggested the basic building regulation information systemization based on construction stages and administrative procedures. Focusing on the regulation information system, administrative procedures and application standards by building usage, regulation information system based on construction-related experts, and the systems to response to various needs of users will be additionally developed.

\section{Acknowledgement}

The study is part of the result conducted by Korea Institute of Construction Technology in 2015.(Task No.: 15AUDP- B087012-02) with research funding support from the urban construction research project of the Ministry of Land, Infrastructure, and Transport.

\section{References}

[1] Ministry of Land, Infrastructure, and Transport, Building-related integrated standard (Notice of the Ministry of Land, Infrastructure, and Transport No. 2013-522)

[2] A study on the reorganization of building legislation, Ministry of Land, Infrastructure, and Transport, Korea Institute of Construction Technology (2015)

[3] Development of Korean Building Code, Ministry of Land, Infrastructure, and Transport, Korea Institute of Construction Technology (2015)

[4] Building Act (Enforcement decree of the Building Act, Enforcement rule of the Building Act, regulations, and Rule of the standard for building facilities)

[5] Korea Building Code, Architectural Institute of Korea, Ministry of Land, Tranport and Maritime Affairs (2009)

[6] Small-sized building code (plan), Korean Structural Engineers Association, Architectural Institute of Korea (2011)

[7] Korea Building Code (plan), Architectural Institute of Korea, Ministry of Construction and Transportation (2003)

[8] Korea Institute of Construction Technology, Report on basic plan for performance-bassed building technology standard development (2007)

[9] The 3rd AURI Policy Forum “The Building Act - how it should be changed” (2011)

[10] E.K. Hwang, Y.C. You., A Basic Study for the Systematization of Korean Building Code, Collection of dissertations of academic conferences of the Architectural Institute of Korea, Vol.35 No.2 (2015-10) 